\title{
Marek Ostrowski*
}

iD https://orcid.org/0000-0001-7100-4226

\section{Creation Out of Nothing. The Fascist Propaganda in Litzmannstadt}

Being the fifth largest city of the Reich, the city of Litzmannstadt ${ }^{1}$ was significant in terms of propaganda because its German spirit had been discovered anew, and due to the fact it had become a resettlement centre - Volkdeutsche Mittelstelle. The resettlement process to intermediate camps and later to the villages and towns of Reichsgau Wartheland and the Old Reich applied to tens of thousands of Germans from Volhynia, Galicia and the Baltic States, mainly peasants. The political organisations of the Third Reich mainly faced the major propaganda task of instilling the national socialist world view in the newcomers.

The notion of settlement and colonisation of areas was a key concept in the theoretical output of the Nazi state. Initially, it was a result of the natural tendency to mystical elevation and idealogising the peasant life as the source of national strength. Peasants constituted the natural political force of Nazi ideology, being the example of life strongly bound to the fatherland. Many efforts were made to prevent the rural population from migrating to cities. In order to make life in the countryside the basis for future policy, the authorities supported the theoreticians of peasant colonisation, e.g. Heinrich Sohnrey. In terms of theory, the program of populating areas with peasant colonisers stemmed from the studies on strengthening the German countryside, constituting its further modification. Sohnrey, with the internal situation of Germany mainly in mind, wrote in one of his works: "The complete lack of a safe, peaceful and hopeful place at the warm fire of one's own homeland (Heimstätte) is the first and the main reason for people fleeing the

* Professor, University of Lodz, Faculty of Philology, Chair of Journalism and Social Communication, e-mail: marek.ostrowski@uni.lodz.pl.

1 After the defeat of September 1939, Łódź was incorporated into the Reich and in 1940 it was renamed as Litzmannstadt. Reichsgau Wartheland or das Wartheland was created. 
countryside." ${ }^{2}$ Therefore, Sohnrey proposed a series of actions aimed at preventing the degradation of the rural population. His main proposal was to create a legal act on labourer pensions, which would offer "every professionally active and morally chaste"3 individual the option to purchase a certain amount of land and a residence so that they could feel like true peasants, and to create a legal act on houses for labourers, the aim of which would be to ensure the success of the pension act. In 1894, Sohnrey founded Verein für ländliche Wohlfahrts- und Heimatpflege (Association of rural charity and patriotic care), an association which declared that its purpose and organisation served

a targeted development of healthy internal settlement at the core of which there lies the creation of new social opportunities for the development of the peasant population together with the families of rural labourers. Settlement locations [...] should be defined by rural communes consisting of large, medium, small and the smallest households and areas. That also applies to settling labourers in the countryside. $^{4}$

When the Nazi Party seized power, the the organisations termed Siedlungsgesellschaften $^{5}$ (Settlement Societies) were given new opportunities for utilising the living space in the East. Sohnrey's charitable work also had a spiritual and artistic dimension, ${ }^{6}$

2 H. Sohnrey, Der Zug vom Lande und die soziale Revolution, Verlag von Reinhold Werther, Leipzig 1894, p. 33 [Unless indicated otherwise, English versions of quotations were translated from Polish]. Sohnrey founded the Das Land periodical and in 1908 an archive of internal colonisation (Archiv für innere Kolonisation).

3 Ibid.

4 Ibid., pp. 136-137.

5 The first Siedlungsgesellschaft was like a peasant self-help organisation, and was the model of a non-capitalistic natural settlement. In the brochure Wegweiser für das Land, Sohnrey defined the tasks of a Siedlunggesellschaft to include the organisation of a peasant commune, and its purchasing land and distributing the land between rural labourers. The explicit aim was to "ensure that every diligent and thrifty labourer can within a colony purchase for a minor sum his own home" (Wegweiser für das Land zur Gestaltung und Bereicherung des dörflichen Lebens, Deutsche Landbuchhandlung, Berlin 1939, pp. 113-114). In less than two years, the organisation purchased new settlement locations in Pomerania 171. This ideology resonated with the mystical and racist thought later used by the Nazi Party, the core of which was the practical combination of the notions of: Volk, Blut and Boden. Its purpose was to create an internal relationship with the people (Volk). The Nazis expanded on Sohnrey's thought by adding the notions of Raumgestaltung and Landschaftsgestaltung, which were planned spatially in accordance with the principles of national socialist aesthetics.

6 Sohnrey wrote: "Peasant life is close to the nature not because peasants work with plants and animals [...], but because life in the countryside strengthens family bonds, and it is life for the family" (idem., Wegweiser für das Land..., p. 9). He devoted much space to the soul of the 
as in his writings he combined social policy with the natural sciences and folk poetry.

In the Third Reich, the task to properly shape rural life in line with the national socialist spirit, understood as the continuation of Sohnrey's principles and teachings, was fulfilled by the Amt für Dorfgemeinschaftsleben ${ }^{8}$ authority, which was part of the central party structure (Hauptkulturamt der NSDAP). ${ }^{9}$ The Sechs Jahre Neubauern-Auslese $e^{10}$ brochure, published by the Neues Bauerntum periodical, discussed the selection criteria and guidelines for settlement, indicating an increase in candidates for settlement. Around one third of all settlers came from Pomerania, Eastern Prussia, and Silesia. Settlement problems in Reichsgau Wartheland became the topic of academic analyses around 1944. Various specialist periodicals raised it, e.g. Das Wartheland and Wirtschaft und Statistik. The latter published an article by Wilhelm Zoch entitled "Ergebnisse und Erfahrung der Ansiedlung im Wartheland."1 In it the author discussed Litzamannstadt's problem with settling Germans from other areas. At the beginning of 1944, the population of Germans in Reichsgau Wartheland reached 1 million. That meant that nine in ten of all the relocatees of German descent (Volksdeutsche) to the areas acquired during wartime activities came to live there. ${ }^{12}$ That was a result of the resettlement and colonisation program which had begun in 1939. It faced various organisational difficulties: lack of German maps of the areas intended for settlers, lack of state or party structures, and the harsh winter of 1939/1940. ${ }^{13}$ Zoch listed ten settlement waves in Reichsgau Wartheland as a result of which the authorities settled approx. 50,000 Baltic Germans (Baltendeutsche), mostly urban populations, then 90,000 Germans from Galicia, Volhynia and the Narew area mainly in Posen, Litzmannstadt and Gnesen. Germans of peasant descent from Volhynia settled in the east of the land (Wieluń, Łask, Konin, Turek, Łęczyca), Germans from Northern and Southern Bukovina and Bessarabia (approx. 60,000) arrived in 1940-1941 and settled around Sieradz, Ostrów, Krotoszyn and Kalisz..$^{14}$ Moreover, approx. 30,000 Germans were relocated from around Chełm and Lublin. In early 1944, there began the relocation operation of Germans from the Russian territories of the Dnieper and Donetsk

people - Volksseele: "Though the times and circumstances change [...], the soul of the people remains constant." (idem., p. 241).

7 Particularly in Wegweiser für die ländliche Wohlfahrtsarbeit, Aufl. 4, Berlin 1930.

8 Office for the affairs of the rural communal life.

9 The office was headed by Martin Bormann.

10 Neues Bauerntum, Deutsche Landbuchhandlung, Berlin 1940.

11 W. Zoch, "Ergebnisse und Erfahrung der Ansiedlung im Wartheland" Wirtschaft Und Statistik 1944, H. 2, Februar, pp. 156-161.

12 Propaganda-natured data (ibid., p. 156).

13 Cf. Wirtschaft und Statistik 1944, February, p. 156.

14 Ibid., map p. 158. 
and from eastern Volhynia and Polesia. ${ }^{15}$ Another group of Germans came from the areas of the Black Sea, Bessarabia, Dobruja and the Ukrainian steppes, stretching from the Bug to the Don. ${ }^{16}$ Litzmannstadt was subjected to the settling of various mixed ethnic groups. Thus, the atmosphere of the city was dominated by its inhabitants' uncertainty concerning their future, powerful Germanisation, and forced settlement and relocations. ${ }^{17}$

Already in December 1939, a special commission of around 300 people arrived in Volhynia. Working in primitive and hastily erected offices for even twenty hours a day, they developed a census of the relocatees and their belongings. The commission also worked in Galicia and the basin of the Narew. The recolatee population totalled 130,000 people. Their main destination was the area of Reichsgau Wartheland, from where in late-1939 and at the beginning of 1940 approx. 87,000 Poles were displaced so that the colonists from Volhynia, Galicia and the area of the Narew could settle in their property. It was planned that another 80,000 were to be displaced in 1940 to the General Government. ${ }^{18}$

Such an extensive relocation operation posed a huge logistical challenge, especially in wartime. Therefore, it is no surprise that approx. 100,000 relocatees did not immediately receive abandoned Polish property, and they had to spend the time in special camps called Beobachtungslager ("observation camp"). Litzmannstadt played a major role in those plans. In organisational terms, it became the centre of the relocation operation. It received the relocatees who were directed to the temporary Beobachtungslagern. They role was fulfilled not actually by any purpose-built barracks but rather buildings from which Poles and Jews were expelled, allotments, factories and school buildings within the Łódź city limits, as well as in Pabianice, Zgierz and Kalisz. Special commissions worked at those camps studying the usefulness of the newly arrived "ethnic individuals" in terms of race biology. They analysed family histories and verified personal details, and then decided whether to grant them Reich citizenship and the ability to settle in Reichsgau Wartheland

15 Germans from Bukovina and eastern Galicia have been termed Carpathian Germans (Old Austria - Altösterreich).

16 The article was based on the speech of Artur Greiser entitled Der Aufbau im Osten, printed in an issue of the Kieler Vorträge 1942, H. 68, pp. 15-26.

17 An interesting introductory study into the matter was offered by Otto Heike, a well-known Łódź German. He wrote that the colonisation operation began already in 1939. By the end of 1940, over 15,000 families were settled in the eastern part of Reichsgau Wartheland, with the largest group, i.e. 5,500 families, in Łódź and around it. Over 1,500-2,000 families were settled in Kutno, Łęczyca, Łask, Sieradz and Wieluń, between 600 to 1,000 in Kalisz, Turek and Gostynin, and several hundred around Ostrów, Września, Jaroszyn, Krotoszyn, Wągrowiec, Płock and Konin (O. Heike, Das Deutschtum in Polen 1918-1939, own publication by Otto Heike, Bonn 1955, p. 27).

Ibid. 
or at another location in the Reich. ${ }^{19}$ The relocation operation entailed casualties: difficult sanitation conditions, exhaustion due to long journeys, and poor immunity to various illnesses in general resulted in high mortality among the relocatees. Of course, Nazi propaganda covered up any such instances; the preferred image was one of a physically strong Volhynia peasant who could endure much.

A separate propaganda task was the ideological formation of the newcomers. This included shaping assumptions regarding the stereotype of being German, which entailed specific expectations of cultures defined as ethnic communities and the source of race. Those requirements included people's proper adjustment to the racial model, understood in physical terms as a set of skull and facial dimensions, and body proportions, as well as a specific personality profile.

Being the centre of relocation, Litzmannstadt operated in line with the racial policy of the Reich, providing hundreds of thousands of relocatees to fulfil the principle of homogeneity of the Reich area in language and ethnic terms. Therefore, the efforts to populate the areas which once had belonged to Poland also entailed propaganda and political activities, in which mostly women's and youth associations participated, such as Hitlerjugend, BDM, and NS-Frauschaft. ${ }^{20} \mathrm{Ma}-$ ria Fiebrand stressed the fact that after relocation, healthcare for the newcomers mainly meant racial hygiene, which became the focus of the healthcare services in Reichsgau Wartheland. ${ }^{21}$

The reproductive value of the race was particularly important for the centre of relocation in Litzmannstadt. The authorities began sterilising relocatees without consulting the local healthcare services or the actual subjects. Therefore, the main objective of the operation conducted by the Einwandererzentralstelle headquarters was to

19 In Reichsgau Wartheland, relocatees were mainly settled in the countryside: just over 78,000 people. They were classified under one of four categories, depending on their value in racial terms. The majority was classified under group 3, i.e. received a low evaluation, being members of ethnic groups. Cf. S. Döring, Die Umsiedlung der Wolhyniendeutschen in den Jahren 1939 bis 1940, Peter Lang, Frankfurt am Main 2001, p. 214.

20 The number of publications on the propaganda importance of those Nazi organisations in organising relocation operations has been growing consistently. In terms of the major ones, one should mention the studies written in the People's Republic of Poland by Polish researchers (cf. Cz. Madajczyk, Polityka III Rzeszy w okupowanej Polsce, vol. 1-2, PWN, Warszawa 1970; Zamojszczyzna - Sonderlaboratorium SS. Zbiór dokumentów polskich i niemieckich z okresu okupacji hitlerowskiej, Cz. Madajczyk (ed.), vol. 1-2, Ludowa Spółdzielnia Wydawnicza, Warszawa 1977), as well as contemporary German studies, mainly Maria Fiebrandt's book Auslese für die Siedlergesellschaft. Die Einbeziehung Volksdeutscher in die NS- Erbgesundheitspolitik im Kontext der Umsiedlungen 1939-1945 (Vandenhoeck@Rupracht, Göttingen 2014, p. 484 [Selection of the relocatee population. Entangling ethnic Germans in the national socialist policy of healthy racial heritage in the context of the 1939-1945 relocations]).

21 E. Fiebrandt, op. cit., p. 39 and the following. 
suppress the biological hazards for the race which could have been potentially posed by the relocatee population. The sterilisation operation was expanded to also include Polish children, so as to weaken the biological strength of the Polish nation. ${ }^{22}$ One of the most noteworthy publications on the subject was written by Marcus Leniger. In his book entitled Nationalsozialistische „Volkstumsarbeit” und Umsiedlungspolitik 1933-1945. Von der Minderheeitenbetreuung zur Siedlerauslese ${ }^{23}$ he concentrated on the presentation of the fortunes of the relocatees displaced between October 1939 and 1942 from eastern and southern Europe to Germany. The propaganda apparatus promoted the benefits of the operation to them. In reality, though, they were treated by various commissions as aliens, a "racial risk." Having been placed in special camps referred to as Umsiedlerlager, they were subjected to indoctrination and continuous control of their world view. The main goal was to strip them of the identity they carried from their places of origin, distinctive folk customs, and their ways of life. They were subjected to harassment, which often ended in them being sent to concentration camps. Therefore, the theory of race was a major part of the propaganda efforts. ${ }^{24}$ It was crucial in the case of relocatees. The commissions established for that purpose tested the newcomers specifically in terms of their racial patterns. Depending on the results, they were directed inland into the Reich, the so-called Old Reich or Altereich, or remained in Reichsgau Wartheland. One can find out what those tests looked like by studying the publications written under the academic supervision of Prof. Egon Freiherr von Eickstedt, the director of the Institute of Anthropology at the Breslau University, and Ilse Schwidetzky, his assistant. One of Eickstedt's major research goals was to study the Upper Silesian population in terms of racial patterns. That goal was fulfilled in a series of publications entitled Rasse, Volk, Erbgut in Schlesien. The second volume of the series by Ilse Schwidetzky, Ph.D., was published by Fritz Arlt, the head of the racial policy office at the office of the Silesian Governor (Rassenpolitisches Amt bei der Gauleitung) and the Silesian national office for racial affairs (Landesamt für Rassen-Sippen- und Bevölkerungswesen). The publication was entitled Badania rasy północnowschodniego Ślaska (okręgi Kluczbork,

22 Ibid., p. 389.

23 M. Leniger, Nationalsozialistische "Volkstumsarbeit" und Umsiedlungspolitik 1933-1945. Von der Minderheeitenbetreuung zur Siedlerauslese, Frank\&Timme GmbH, Berlin 2006, p. 146 and the following. [National socialist "work with the nation and the 1933-1945 relocation policy. From care over ethnic minorities to selection of relocatees].

24 It was particularly important for the lives of the citizens of the Third Reich, due to the Nuremberg Acts, which permitted only people of the Aryan race to hold German citizenship. In many situations, e.g. when getting married or undertaking employment, it was necessary to provide a certificate of Aryan descent, which was issued by the Ministry of the Interior of the Reich (Reichsinnenministerium) in its division called Reichstelle für Sippenforschung, later converted to Reichssippenamt. The racial certificates were fundamental for establishing whether a person was of Jewish descent (the so-called Jewish issue - die Judenfrage). 
Olesno, Dobrodzień) (Rassenkunde des nordöstlichen Oberschlesien [Kreise Kreuzberg, Rosenberg, Guttentag]) [Studies of the race of north-eastern Silesia (districts of Kluczbork, Olesno, Dobrodzień]. It discussed the results of the anthropometric research conducted on the Silesian population with the distinct assumption that race was related to one's place of residence, land, and the landscape of the country of origin, in short: it defined the qualitative notion of localness. There were more representative, i.e. racially better, types of local communities. Racial characteristics were transmitted genetically, and it was assumed that they could be diluted..$^{25}$ The starting point of an examination was the identification of the individuals featuring maximum racial purity for a given race, and the definition through measurements of the developmental intermediary types between races. That was supposed to add to the research on the characteristics of local ethnic groups. ${ }^{26}$ The results of those tests were used for propaganda purposes, for portraying racially perfect local types. In the same manner, the political propaganda authorities in Litzmannstadt framed the specific type of a German from the area. That image was present in the media of that period as an illustration of one of the cultural roots of race.

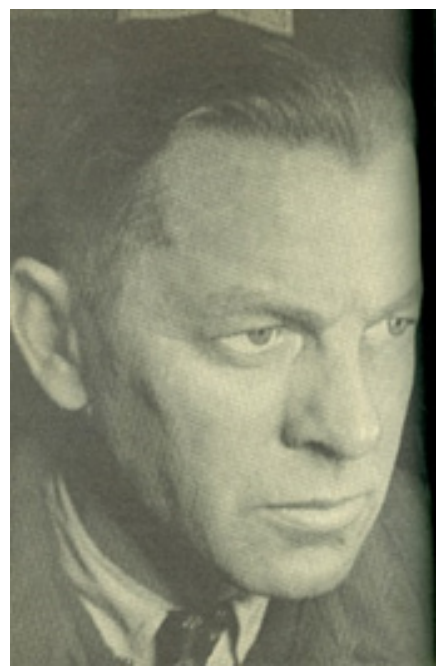

Photo. Model German Litzmannstadt labourer

Source: Der Osten des Warthelandes. Herausgegeben anläßlich der Heimatschau in Litzmannstadt, Hrsg. H. Müller, Stähle\&Friedel, Stuttgart 1940.

25 In his main work Rassenkunde und Rassengeschichte der Menschheit (1934), Eickstedt divided races into Europide, Mongolide, and Negride.

26 Of course, the tests consisted of measuring a person's physical characteristics, i.e. height, dimensions of the skull (length and width) with particular consideration of the total length of the face, and the proportionally measured size and shape of the nose and cheek bones. Examiners defined the colour of a subject's hair and eyes. The measurements were exact, i.e. provided in millimetres. 
The centre for relocation was called Volksdeutsche Mittelstelle Einsatzstab Lodsch. It received trains full of relocatees from Galicia, Volhynia and the Narew area (the Bialystok district). Volksdeutsche Mittelstellen also existed in the Reich (Rheinefelde and Saalfeld in Turingen, and Templin - Ackermark, LichterfeldeSüd). It was reported triumphantly by Lodzer Zeitung. ${ }^{27} \mathrm{~A}$ few weeks later the newspaper reported on the nearing end of the operation. The article "100,000 Rückgeführte. Die Rückführungsaktion vor dem Abschluss" reported on the extent of the propaganda operation:

Yesterday, Burgstadt [Kórnik] received train no. 386B, which brought a group of refugees totalling one hundred thousand [...] In celebration of that the train station was festively decorated. The locomotive pulling into the station was decorated with a wreath with a sign "100,00o." Obersturmbannführer Woppler, the manager of the relocation headquarters, offered the newly arrived Volhynia folk [Volksgenosse] cordial words of welcome indicating the gravity of that historic event $\left[\ldots . .{ }^{28}\right.$

The propaganda vision of Litzmannstadt was probably best described in $\mathrm{Hu}-$ bert Müller's publication entitled Der Osten des Warthelandes. ${ }^{29}$ The book was published to accompany a patriotic exhibition organised by the Ministry of Propaganda of the Reich and it was supposed to present the achievements of the German city. Since it had not been included in German maps, the publication also constituted an attempt at justifying the city's cultural union with the Reich. ${ }^{30}$ Most of all,

27 In the article "Fast ein Drittel wieder im Reich" dated 9 January 1940.

28 Lodzer Zeitung in a issue of 28 January 1940.

29 Der Osten des Warthelandes. Herausgegeben anläßlich der Heimatschau in Litzmannstadt, Hrsg. H. Müller, Stähle\&Friedel, Stuttgart 1940. Müller was a press clerk at the Propaganda Office of the Reich (Reichspropagandaamt).

30 The fact that Łódź became the German city of Litzmannstadt was recorded by German travel guides in 1941. One of those was Reichs-Handbuch der deutschen Fremdenverkehrs-Orte, published by Erwin Jäger Verlag. It provided the following general information on the city: "Litzmannstadt is the seat of several important party and state offices, and the central point of the relocation operation - it lies at the intersection of three main routes which form transport axes: Central Germany - Central Russia, the Baltic - the Black Sea, and the Adriatic - the Baltic. In cultural and economic terms, it constitutes the central point of eastern Reichsgau Wartheland. The largest city of the Reich east of the Oder with a population of approx. 600,000 , the largest German city of the textile industry ensuring over $10 \%$ of the total German textile production. Its population includes approx. 110,000 Germans, partly relocated (Balten, Bessarabiern, Galiziern and Wolynierndeutsche), and Poles. The land elevation within the city limits varies between $170 \mathrm{~m}$ a.s.l. in the south-west and $270 \mathrm{~m}$ a.s.l. in the north-east. The city is located between the water routes of the Oder and the Vistula." (Reichs-Handbuch der deutschen Fremdenverkehrs-Orte, Erwin Jäger Verlag, Berlin 1941, p. 520). 
the ancient German history of this area was presented as indisputable. The history of Łódź was being written anew.

Litzmannstadt could not had developed from the city of Łódź without German peasants and craftsmen, whose numbers within the 150 years of their presence there were estimated at approx. 200,000. The main thesis of the publication expressed in the chapter "The East of Reichsgau Wartheland" could be summarised as the position that the commonly known theory of the district's Polish-Russian nature was false. ${ }^{31}$ Its author, Fritz Gissibl, editor of the volume and officer of the Office of Propaganda of the Reich (Reichspropagandaamt), openly stated that the German peasantry had played a vital role of the creators of culture in the area. Under the supervision of Ludwik Wolf, they performed excellent work as a notional minority in central Poland. Their work in the area was referred to by Sigismund Banek, a well-known German poet of the period, as a constant battle.

31 In another study written for high mayor (Oberbürgermeister) Müller, the writer was more radical and struck political propaganda tones with greater intensity. In Litzmannstadt - Deutschlands größte Großstadt baut auf (in the author's repository) one can read the following: "Since the time when Litzmannstradt emerged from the Polish Łódź, the authorities began, with German precision, changing in administrative terms everything that constituted any former value. Even today, the city is undergoing such a change, which once seemed impossible in such a short time and to such an extent. Litzmannstadt already displays the typical main characteristics of a German city. Of course, putting aside the urban architecture, which in the following decades will require extreme changes in the national socialist spirit. [...] Surely there is no other German city where opposites would play such a role as in Litzmannstadt. [...] Side by side you will find grand structures built by the ruling class of former Poland and miserable huts, the Asian stench of which words cannot describe. Until recently, 300,000 Jews inhabited the city, to whom it owed the image of dirt and backwardness. Another typical characteristic of the culture of Poles is that this gigantic city does not have a water and sewage system, which is the reason why the inhabitants often suffer malicious diseases. In fact, the common name for tuberculosis used to be "the Łódź sickness." The lack of hygiene caused by Poles and Jews is the reason why the city evokes anxiety regarding the possibility of coming into contact with contagious diseases; moreover, it is a true Eldorado for all kinds and varieties of insects. A German would not be able to comprehend that even in the most elegant Jewish or Polish flats equipped with every amenity possible, there is so much filth as in the worst of hovels. Since German soldiers moved in and the grand city of the east was taken over by the Reich, the administration has done wonders in terms of combating filth, insects, and sickness. The fact of establishing a closed residential area for Jews will be recorded in the city's history as the most necessary and universal of rectifying means essential for normal development. Only when Jews vanished from the city's streets, did it become possible to make surprising changes, even those strictly external in nature. Litzmannstadt is the first big German city free of Jews. Whoever strolls the city established by Germans has their eyes wide open, realising that it was once subject to the Polish and Russian influence." [typescript] 
Far from the homeland and forced to rely only on themselves, they engaged in a fight with the forces of nature and the destructive influences of the ethnically alien environment. They retained, remaining true to their German blood, their own way of life, their language and the customs of their forefathers. Generation after generation rose the crops of their struggles. ${ }^{32}$

It was typical to refer to Polish work and business activities as detrimental and hostile. The common approach was to use the well-known negative stereotype of "Polish economy" (polnische Wirtschaft):

Huge mismanagement of Poland's ruling class in the period prior to the final disintegration [partitions] of the state led to a total collapse of both state administrative structures and agriculture. To ensure a permanent source of income, Polish landowners leased land to German peasants who came in growing numbers, and who felled centuries old forests. ${ }^{33}$

Thus, according to Banek, within twenty years by 1800, fifty German villages were established in forest areas around Litzmannstadt. The author mentioned the business enterprises of numerous German factory owners: Johann Friedrich Zachert, Karl August Meissner in Zgierz, Benjamin Krusche in Pabianice, Heinrich Schlösser in Ozorków, and, of course, Karl Gottlieb Sänger, Karl Scheibler, Ludwik Geyer and others. He concluded his discussion with a statement that in 1860 Litzmannstadt was already two thirds German. ${ }^{34}$

Another fundamental thesis of the propaganda was that the areas surrounding Łódź were not pre-historically Slavic. When writing about the Germanic history of the areas, Adolf Kargel, an archaeologist, referred to the research of Karl Schuchhardt who had conducted archaeological studies during the First World War. The

32 S. Banek, "Deutscher Aufbau im Litzmannstädter Land", [in:] Der Osten des Warthelandes..., p. 17.

33 Ibid., p. 18.

34 The basic source of knowledge on the history of Litzmannstadt was for the occupying forces a survey conducted for Frederick William II, King of Prussia. In 1793, the Prussian Chamber in Piotrków Trybunalski delivered it to the king. The survey by the Prussian State Archive in Berlin described Łódź as a particularly poor and backward city: "Łódź is a town. The town is completely open, meaning it has no walls, and its streets are not cobbled. In has forty-four stacks (houses). All the houses are wooden, two of those are shingled, 42 are thatched, and there are eleven empty houses. Additionally, there are eleven vacant buildings and 44 barns. Records show there is a Catholic church with a Catholic priest. There are no schools." The question regarding public utility buildings received the answer: "Wooden prison in a very poor shape." As cited in: Preussisches Staatsarchiv in Berlin, 22 April 1794, ref. no. Fasc. 761/15, 909/4, 910/10. 
first findings came from Wilczyca n. Poddębice in the form of stone graves. In a lecture he delivered at the Anthropological Society in Berlin in 1915 and in later publications, ${ }^{35}$ he defined the graves as old-Germanic belonging to the Lusatian period (Lausitzer Periode), ca. 1400-400 BC. Another find which confirmed the indicated thesis was made near Aleksandrów, where archaeologists found Germanic urns dated from the Hallstatt-Periode period, 1100-500 BC. Kargel also referred to the works of Polish archaeologists and their findings: in the village of Zalew n. Lutomiersk and in Gledzianówek in the Witonia commune n. Łęczyca, which included tableware with the sign of the swastika.

Although Polish archaeologists, mainly Prof. Kostrzewski from the University of Poznań, claim that the pre-culture of the period was Slavic and that Germans stayed in the country only during wartime operations, that seems to be contradicted by the exceptional sizes and extents of cemeteries, which would indicate that Germans lived for extensive periods in the lands. ${ }^{36}$

Also, around Biernacice n. Uniejów, researchers found bronzeware (dated as $800 \mathrm{BC}$ ) decorated with the distinct motif of a swan making a circle in the shape of the sun. The author posited that those motifs came from Germanic beliefs. In the Middle Ages, traces of Germanic culture could be found in Christian structures, i.e. chapels erected in the palaces of the rich in Łęczyca, Sieradz and Szadek. In the $12^{\text {th }} \mathrm{c}$., a Roman church in the village of Tum n. Łęczyca was a monument to the mediaeval German culture. The Gothic style was applied to the churches built in Piotrków, Łask and other towns. The first town with a German pedigree was Warta n. Sieradz. It had a German mayor by the name of Wolfram. In the settlement documents of 1255 , the town was referred to by its German name as Libewarde. The names of many citizens of Łęczyca and Szadek, e.g. Wilhelm, Theoderich, Kerstan, Hermann, Kunz and Franz, found in many official documents, indicate the German nature of the areas in the Middle Ages. In that context, researchers listed many villages defined as German, e.g. near Szadek: Wilamów, Wieka Wieś, and Kromolin, near the Cistercian Monastery n. Sulejów: Bałdrzyków, Dabrówka, Iwonie, Piotrów, and Zagorzyce, and, finally, near Pabianice: Chocianowice and Kolno, to name but a few.

During the Second World War, propaganda was mostly disseminated via the press, film and radio. The press was the most widely accessible. A considerable amount of attention was paid by the Nazi propaganda to the history of the German-language Łódź press. The first German-language newspaper was the Lodzer

35 A chapter devoted to the archaeology of the Litzmannstadt district (Der Osten des Warthelandes..., pp. 30-35).

Ibid., p. 32. 
Anzeiger, established in 1863 by Johann Petersilge. Its first issue appeared on 2 December. The newspaper was published twice a week. Initially, it published official texts and announcements and classified ads in Polish and German. From 1865 it was published exclusively in German, three times a week, and under the new name of the Lodzer Zeitung. Pressured by its competition, i.e. the Lodzer Tageblatt, established in 1881 with Leopold Zoner as editor-in-chief and published in a large format six times a week, the Lodzer Zeitung was forced to change its format and adjust to its competitor's frequency of publication. In 1902 the Lodzer Tageblat ${ }^{37}$ was bought by Alexis Drewing and Alexander Milker, and it was turned into the Neue Lodzer Zeitung. ${ }^{38}$ From 1904 both German language Łódź newspapers were published twice a day. Both newspapers were, politically speaking, moderate, they offered a wide perspective and a distance towards Russian and Polish matters. A truly German nationalist profile, as stressed by Nazi propaganda officers, was eventually offered by the Lodzer Rundschau, which was published for two years after 1911. During the First World War, there was also, for a short time, the Deutsche Lodzer Zeitung (an altered title of the Lodzer Zeitung) and the Deutsche Post. During the interwar period, German-language press mainly consisted of the Lodzer Freie Presse, whose editorin-chief was Adolf Kargel. Periodicals were also published after November 1918 by Verlagsgesellschaft Lodzer Freie Presse m.b.H.; it also operated a bookshop and the Libertas press house. The same publishing house ran a newspaper for German peasants: the Volksfreund (August Utta was its editor-in-chief). Also, there was the Der Deutsche Weg (with Ludwig Wolff as its editor-in-chief), which was an outlet of the Der Deutsche Volksverband association. Nazi propaganda proudly stated that during the interwar period one fourth of all newspapers and magazines in Poland were published in German. One fact is that, after 1933, there were published such titles as the Völkischer Anzeiger (between January 1935 until 1937) and the Deutscher Volksbote with the supplement Der Deutsche Lehrer in Polen, which were partly financed by the Third Reich and shared its world view bias.

Since Litzmannstadt and the Łódź district on the Warta were defined by the propaganda as genuinely German lands, the life of Germans in the area prior to 1939 was described in terms of ethnic struggles with the Polish element. The formation of the Polish state was described as an ethnic catastrophe for Germans. In trying to defend themselves from losing their identity, they established numerous organisations of a political nature. ${ }^{39}$ In 1923 , August Utta, a deputy for the Sejm

37 The newspaper was published after 1905.

38 From 1933 an outlet of Jungdeutsche Partei. The periodical is available in the digital library of the University of Lodz at: http://www.bcul.lib.uni.lodz.pl/dlibra/publication?id=4996\&tab=3 [accessed on: 18.01.2019].

39 Surely that was facilitated by the fact that by being a minority, they were represented in the Sejm of the Polish Republic. 
and later a senator, created a political party called Deutscher Volksverband. Nazi propaganda only considered Utta's association and Jungdeutsche Partei as parts of their history, excluding the Deutscher Kutur- und Wirtschaftsbund ${ }^{40}$ organisation, which it considered under the Polish influence and defined it as a nationalist mock organisation. The authorities unequivocally rejected any relations with Deutsche Sozialistische Arbeiterpartei, a labourer organisation, termed as a leftist-Marxist organisation inspired by the leftist forces of the old Reich. After Józef Piłsudski came to power in 1926, the number of representatives of Łódź Germans in the parliament fell from six to just one. The period after 1933 was most intensively used by Jungdeutsche Partei headed by Rudolf Ernst Wiesner. The consolidation of the activities of German parties, particularly in the countryside, was largely aided by the non-aggression pact between the Reich and Poland of 26 January 1934. From that moment on the parties intensified their propaganda operations in Łódź and the surrounding area. The outcomes of that became clear in 1938 when over 20,000 votes were cast in favour of the uniform German list during communal and Sejm elections. The German minority received six spots on the City Council.

One important characteristic of Nazi propaganda was the fact that it had a considerable impact on the activities of the government authorities in Litzmannstadt. While following the official world view of the Reich, the propaganda also formulated the guidelines for the governing administrative bodies. It was particularly visible in the case of the centre for relocation.

The necessity of ensuring residence for the Germans relocated from Volhynia, Galicia, the district of the Narew and the Baltic States put the municipal administration (Stadtverwaltung) in a difficult position. It was necessary to assign residence for the officials from the Reich invited to work in Litzmannstadt who were drawn to the province with the promises that their standard of living would be improved. That was indicated both in the monthly reports of the municipal administration (Stadtverwaltung Litzmannstadt) sent to the mayor in $1940,{ }^{41}$ and in the political reports of the office responsible for the relocations, i.e. Volkspflegeamt. ${ }^{42}$ On 11 May 1940, an officer by the name of Karutz ${ }^{43}$ wrote his April report (Lagebericht) to the mayor. It stated that the Reich Governor Arthur Greiser and his office acting as

40 The association ran the periodical Deutscher Volksbote: Wochenschrift für Politik, Kultur, Wirtschaft und Verständigung. The periodical is available in the digital library of the University of Lodz at: http://www.bcul.lib.uni.lodz.pl/dlibra/publication?id=24638\&tab=3 [accessed on: 18.01.219].

41 Stadtverwaltung Litzmannstadt: monatliche Lageberichte der Ämter 1940 (in the author's repository).

42 Monatsberichte der Stadt Litzmannstadt. Volkspolitische Lageberichte des Volkspflegeamtes 1943,44 (in the author's repository).

43 Officer at Umsiedlungs- Quartier- und Wohnungsamt (Office for relocation, quarters, and flat affairs). 
the commissioner for the defence of the Reich (Reichsverteidigungkommisaar) in the district (Gau) of Wartheland assigned Litzmannstadt's high mayor Marder the right to requisition in the city flats from Poles. Once cleared by the Treuhand Trust agency, they could be assigned to relocatees and Germans, with priority offered to those who came to Łódź from the Reich. On 30 April 1940, the relocation headquarters for the Baltic Germans concluded its operations. After then, any settling of newcomers was the responsibility of the Umsiedlungsamt office managed by one Friedrich Engels. Based on the indicated report, it seems he assigned the right to settle in 6,787 cases out of the total of 7,408 Baltic Germans directed for settlement, and in the previous reporting month 306 persons out of 927 applicants. Despite the evictions of Poles and thus gathering a considerable number of flats (reports indicated 4,500 empty flats and 1,500 furnished ones), there was a large demand for residence. Engels stated in a letter of 1 June 1940 that he assigned flats to 308 out of the 320 Baltic Germans who arrived in the city. ${ }^{44} \mathrm{He}$ also informed the high mayor Marder that he made approx. 600 requests with the officers who arrived in Litzmannstadt from the Reich who lived in furnished flats to render available one bedroom for the City Hall's disposal. Therefore, the evacuation operation caused major residential difficulties in the city, and despite that the relocated Germans received a preferential treatment from the Umsiedlungsamt office.

The activities of the propaganda of the Third Reich in Litzmannstadt perfectly illustrated work in line with the national socialist world view (assuming the genuineness of the ideology). It was understood as a few fundamental principles based on the spiritual, personality and racial unity of the notion of a nation: Volk. The purpose of political and military operations was to restore and maintain the ability to culturally dominate other nations. The Nazi state was ethnically, linguistically and racially homogeneous-it knew not the notion of tolerance towards ethnic minorities. The central notion of the ideology was the nation as an ethnic community, land, and leadership in struggle. The guiding principle of the world view was the fight for the dominance of the stronger over the weaker, i.e. a complete negation of the fundamentals of humanism. This extremely idealised world view, detached from reality, was imposed with the utmost intensity not so much on Poles as, in the form of unrelenting indoctrination, on the relocatees in the camps of the centre of relocation. Tempted by the propaganda promises, they left their property and more or less stable lives in the east to, in the new surroundings, be subjected to racial selection and, in turn, sometimes to forced sterilisation or euthanasia. An important characteristic of the propaganda was its influence on the operations of the administration; one could venture the claim that with its program it formulated the "guidelines" to be fulfilled by the municipal administration of Litzmannstadt.

44 From the author's repository. 


\section{Bibliography}

Banek S., "Deutscher Aufbau im Litzmannstädter Land", [in:] Der Osten des Warthelandes. Herausgegeben anläßlich der Heimatschau in Litzmannstadt, Hrsg. H. Müller, Stähle\&Friedel, Stuttgart 1940, pp. 17-27.

Der Osten des Warthelandes. Herausgegeben anläßlich der Heimatschau in Litzmannstadt, Hrsg. H. Müller, Stähle\&Friedel, Stuttgart 1940.

Döring S., Die Umsiedlung der Wolhyniendeutschen in den Jahren 1939 bis 1940, Peter Lang, Frankfurt am Main 2001.

Fiebrandt M., Auslese für die Siedlergesellschaft. Die Einbeziehung Volksdeutscher in die NS- Erbgesundheitspolitik im Kontext der Umsiedlungen 1939-1945, Vandenhoeck@Rupracht, Göttingen 2014.

Greiser A., "Der Aufbau im Osten”, Kieler Vorträge 1942, H. 68, pp. 15-26.

Heike O., Das Deutschtum in Polen 1918-1939, own publication by Otto Heike, Bonn 1955.

http://www.bcul.lib.uni.lodz.pl/dlibra/publication?id=24638\&tab=3 [accessed on: 18.01.219].

http://www.bcul.lib.uni.lodz.pl/dlibra/publication?id=4996\&tab=3 [accessed on: 18.01.2019].

Leniger M., Nationalsozialistische „Volkstumsarbeit“ und Umsiedlungspolitik 1933-1945. Von der Minderheeitenbetreuung zur Siedlerauslese, Frank\&Timme GmbH, Berlin 2006.

Litzmannstadt - Deutschlands größte Großstadt baut auf (in the author's repository). Madajczyk Cz., Polityka III Rzeszy w okupowanej Polsce, vol. 1-2, PWN, Warszawa 1970.

Monatsberichte der Stadt Litzmannstadt. Volkspolitische Lageberichte des Volkspflegeamtes 1943,44 (in the author's repository).

Neues Bauerntum, Deutsche Landbuchhandlung, Berlin 1940.

Preussisches Staatsarchiv in Berlin. Geheimer Südpreussischer Register 761, 909, 910.

Reichs-Handbuch der deutschen Fremdenverkehrs-Orte, Erwin Jäger Verlag, Berlin 1941.

Sohnrey H., Der Zug vom Lande und die soziale Revolution, Verlag von Reinhold Werther, Leipzig 1894.

Sohnrey H., Wegweiser für das Land zur Gestaltung und Bereicherung des dörflichen Lebens, Deutsche Landbuchhandlung, Berlin 1939.

Sohnrey H., Wegweiser für die ländliche Wohlfahrtsarbeit, Leipzig 1930.

Stadtverwaltung Litzmannstadt: monatliche Lageberichte der Ämter 1940 (in the author's repository).

Wegweiser für das Land zur Gestaltung und Bereicherung des dörflichen Lebens, Deutsche Landbuchhandlung, Berlin 1939. 
Wirtschaft und Statistik 1944, Februar.

Zamojszczyzna - Sonderlaboratorium SS. Zbiór dokumentów polskich i niemieckich z okresu okupacji hitlerowskiej, Cz. Madajczyk (ed.), vol. 1-2, Ludowa Spółdzielnia Wydawnicza, Warszawa 1977.

Zoch W., "Ergebnisse und Erfahrung der Ansiedlung im Wartheland", Wirtschaft Und Statistik 1944, H. 2, Februar, pp. 156-161.

Marek Ostrowski

\section{Kreacja z niczego. Faszystowska propaganda w Litzmannstadt}

\section{Streszczenie}

Artykuł omawia działalność propagandy nazistowskiej w Litzmannstadt. Propaguje ona centralne pojęcia ideologii faszystowskiej, takie jak Volk, ziemia i przywództwo $\mathrm{w}$ walce. Celem działania politycznego i militarnego jest przywrócenie i utrzymanie zdolności dominacji kulturowej nad innymi narodami. Państwo nazistowskie jest jednolite etnicznie, językowo i rasowo - nie zna pojęcia tolerancji wobec mniejszości etnicznych. Istotną cechą tej propagandy jest jej wpływ na działania organów administracyjnych.

Słowa kluczowe: Litzmannstadt, propaganda nazistowska, Il wojna światowa.

\section{Creation Out of Nothing. The Fascist Propaganda in Litzmannstadt}

Summary

The article discusses the activities of Nazi propaganda in Litzmannstadt. It promotes the central notions of the Nazi ideology, such as Volk, land, and leadership in struggle. The purpose of political and military operations was to restore and maintain the ability to culturally dominate other nations. The Nazi state was ethnically, lin- 
guistically and racially homogeneous - it knew not the notion of tolerance towards ethnic minorities. A major characteristic of the propaganda was it its influence on the activities of administrative bodies.

Keywords: Litzmannstadt, Nazi propaganda, Second World War.

Marek Ostrowski - professor, since 2012 employee of the Chair of Journalism and Social Communication, University of Lodz. His academic interests include: philosophy of the media, media in dictatorships, literature within the communicational aspect, propaganda of totalitarian systems (Third Reich, PRL, USSR, DDR). He also studies historical politics and rhetoric in politics. 